\title{
Social Construction of Institutional Complementation in Cross Sector Collaborations: An Empirical Exploration of a Public Private Partnership Case
}

\author{
Moses Onyoin and Christopher H. Bovis \\ University of Hull, United Kingdom
}

\begin{abstract}
Despite an increasing adoption of cross sector collaborative models, especially contractual Public Private Partnerships (PPPs), as an important public services delivery modality, PPPs continue to experience serious institutional gaps that challenge the course of their implementation. This paper utilizes the new institutionalism theoretical lens and draws on interview and documentary evidence from a concession-type Infrastructure Public Private Partnership Project to foreground the different mechanisms used to remedy contractual gaps that are, inadvertently, necessarily or strategically, left open by contracting partners due to the lack of sophistication in setting efficient and precise institutions at the contracting phase. The study discerns the primacy of three socially constructed institutions complementation mechanisms including (a) contract renegotiations and amendments, (b) the development of new regulatory guidelines and standards, and (c) the establishment of inclusive coordinating structures. Based on the evidence, the paper argues that when confronted by emergent and unique challenges unanticipated in the elaborate contractual provisions, there still remains viable opportunity through an ongoing, concerted, and in a collective manner for responsible actors to complement initial institutions in a way necessary to overcome challenges and stay the main cause of the partnership. Other implications relating to specific sector structures and sector regulation are highlighted along with insights for future work.
\end{abstract}

Keywords: Public Private Partnerships; Contractual Gaps; Institutions Complementation; Inclusive Coordinating Structures; Public services 


\section{Introduction}

The popularity of contractual Public Private Partnership (PPPs) as an important approach for the organisation and provision of public services is increasingly evident (De Schepper et al., 2015; Hodge \& Greve, 2010). Understood generally as a longterm co-operation between public and private actors in which actors develop mutual products and/or services and in which risk, costs and benefits are shared (Flyvbjerg, 2010; Koppenjan, 2005; Van den Hurk, 2016), PPPs rationalizations have ranged from fiscal and efficiency considerations in the delivery of public services to acknowledgment of power and influence of contemporary society (Bovis, 2014; Cohen and Boast, 2016; Newberry and Pallot, 2003).

Relative to other modes of collaborations, PPP's operations are highly predicated on peculiarly predefined set of assumptions, standards and rules predefined at the contracting phase (Cohen and Boast, 2016; De Schepper et al., 2014). At the implementation phase, however, these sets of institutions are inevitably confronted by realities that challenge their efficacy (Flyvbjerg, 2010; Newberry and Pallot, 2003; Opawole and Jagboro, 2017). In particular, three important realities present during the implementation of public private partnerships programmes and projects.

Firstly, implementation is characterized by changes to the anticipated circumstances at the pre-contractual phase. More often than not, PPPs faced with major challenges as result of the circumstances that were not readily anticipated during the pre-contractual activities of planning, feasibility study, bidding and negotiation. The nature of the challenges will vary from country context, sector and type of PPP. Some scholars suggested clever contracting through proactive anticipation of the possible changes in the planning phase and providing for flexible contracts that are capable of adapting to the changing circumstances (De Schepper et al., 2014; Trebilcock and Rosenstock, 2015; Van den Hurk, 2016).

Indeed, at an international level, effects of emergent changes on PPP projects are bound. Based on a sample of 258 projects in 20 nations, Flyvbjerg (2010) concluded that substantial cost escalation is not uncommon, where average cost escalation for rail is $45 \%, 20 \%$ for roads, and $34 \%$ for tunnels and bridges. Similarly, Demirel et al. (2017) cite an investigation by the Court of Audit in the Netherlands (2013) of five DBFM projects involving two major roads and three utility projects in the Netherlands in which a total of one hundred and fifty seven (157) uncalculated changes resulted in cost overruns amounting to 61 million euros.

Such reflections of disconnect between the anticipations at the pre-contractual phase and the realities of implementation are abound (De Schepper et al., 2015). As Flyvbjerg et al. (2003, p. 6) put it: "the world of megaprojects' preparation and implementation is a highly risky one, where things happen only with a certain probability and rarely turn out as originally intended".

Secondly, the underestimated complexities at the pre-contractual phase are often revealed at the implementation stage. As many authors observe, insufficient

International Journal of Management and Applied Research, 2021, Vol. 8, No. 2 
understanding of the complexity of PPP environment is a major contributor to a large volume of sunken investments as well as to many project failures (Cantarelli et al., 2012; De Schepper et al., 2014; Flyvbjerg, 2010). PPPs involve a multiplicity of contractual arrangements involving multiple actors that come together in a network of social connections, mutual commitments and specific contract clauses to deliver an intended objective (Flyvbjerg, 2010).

Inevitably, however, partnership stakeholders change along with their interests and priorities (De Schepper et al., 2014). Different actors bring different strategies, procedures and priorities to the project that trigger high level of unpredictability (De Schepper et al., 2014). It is a regular experience that most significant sources of change in the PPPs emerge from the interactions of various stakeholders (Cohen and Boast, 2016; De Schepper et al., 2014; Yang et al., 2018). Indeed, research attributes many failures not only to single factors but to interactions of multiple factors during the lifecycle of the projects -including cost, quality, schedule, management ability, and others (Koppenjan, 2005; De Schepper et al., 2015; Van den Hurk, 2016).

Thirdly, most PPP projects are agreed for periods between 20-25 years and can vary depending on the circumstances of each project case and the needs and demand of partners. Compared to other forms of traditional procurement of services, the longevity suggests a prolonged period of interaction and interdependence between partners. However, in this period neither the activities to deliver a partnership outcomes nor partnership environment are stable (Demirel et al., 2017) as such the changing circumstance are bound to impact PPPs long term commitments.

These three broad and important realities reflect the distinctive character of the implementation phase of PPP that also suggest active issues. First, in relation to the efficacy and sufficiency of the contract as a control instrument, these realities may undermine the remedial capability of the contract as set of institutions. As Johnston and Gudergan (2007, p. 577) suggested that 'technical-rational processes, contractually derived or even contrived post hoc the initial contract, are unlikely to act as effective governance tools'. In other words, apparently reasonable contractual provisions may not be sufficiently powerful to remain relevant throughout the long period of the PPP.

Secondly, the realities and distinctive character of the implementation phase suggests the requirement for actors to adaptively manage the partnerships. In particular, as new complexities emerge during the implementation, so do new challenges, thus creating a necessity for continuous development and application of standards. Thirdly, the postcontractual realities and character are distinctive and context specific. The uniqueness of context such as country and/or sector of PPP application require projects be dealt within their own context (Cohen and Boast, 2016).

In essence, these realities explicate that contractual incompleteness tests overall PPP institutional capacity to anticipate, plan and respond to implementation contingencies necessary for enforcement of long-term collaborations. In other words, the inability to anticipate and provide for all uncertainties at the initial contracting phase makes contracts unlikely and less powerful enough to sustain their rationality throughout the

International Journal of Management and Applied Research, 2021, Vol. 8, No. 2 
full length of the PPP (Johnston and Gudergan, 2007; Newberry and Pallot, 2003; Sadran, 2004). In that regard, actors must continuously consider ways to institutionally adapt to the realities. This is the concern that this paper seeks to address by answering the question: how do PPP actors adapt incomplete institutions, particularly the contract, to respond to the realities of emergent challenges?

As elaborated later, this paper foregrounds three socially constructed mechanisms derived from unique experiences that illustrate how actors overcome emergent challenges by complementing initial sets of institutions in an ongoing and collective manner.

The succeeding part of this paper is organized as follows. Section two briefly explains the theoretical orientation of the paper. The section explains the important elements of new institutional theory as frame of reference for analysis of evidence. Section three describes and rationalizes the materials and methods, section four presents the findings and discussion and section five provides the conclusion and implications.

\section{The New Institutionalism}

John Meyer and Brian Rowan (1977), Paul DiMaggio (1988), Richard Scott (1987) and Lynne Zucker (1987) formulated the initial neo-institutional premises. The concept of institutionalism extended the explanations for the reality of organisational structure beyond the dictates of resource dependencies and technical demands. The lens foregrounded the influence of institutional forces such as rational myth and other knowledge legitimated by law, common public opinion, professions and education system. Fundamentally, the neo institutional lens promulgated the idea of organisations' embeddedness in the social and political environments and as such, practices and structures either mirror or are responses to norms, conventions and beliefs established in the wider environments (Peters, 2019; Powell and DiMaggio, 2012). In other words, organisational practices and structures are nested in the peculiar environmental dynamics.

Two treatments of new institutionalism are particularly informative in the context of institutionalised cross sector in non-homogenous social-political sectional and national environments in which these collaborations occur. The first treatment is Powell and DiMaggio's means of institutional reproduction which emphasise institutional development arising from mimetic, normative and coercive processes. Factors involving or relating to state force, political pressures, and regulatory oversight and control constitute coercive processes. On the other hand, the potent influence of education and professional standards build onto normative factors while the habitual taken-for-granted responses to uncertainty constitute mimetic forces (Powell and DiMaggio, 2012).

The second key treatment is Scott's three 'pillars' of institutional order of normative, regulative, and cultural/cognitive (Scott, 2010). The normative pillar places emphasis on evaluative and obligatory elements, Regulative dimension emphasize rule setting and sanctioning, and on the other hand the cultural/cognitive factors encompass

International Journal of Management and Applied Research, 2021, Vol. 8, No. 2 
common conceptions and frames of drawing and understanding meaning. Principally, each of the pillars offers an altered foundation for legitimacy, either as legally sanctioned, morally endorsed, or culturally buttressed. As noted by Peters (2019), these two treatments of institutional mechanisms more prominently underlined the necessity to distinguish if an organization conforms out of expedience, a moral obligation, or because organisational members are contrived to particular way of acting and find it difficult to conceive alternatives. In the context of this study, both treatments also offer the opportunity to framework the discernment of how institutions develop to fill institutional voids.

To be certain, organizations and organizational practices and structures are fashioned by varying combinations of these elements, changing among one another and over time. As such an important analytical task is to ascertain the element's institutional shaping power in particular context and, if any, the extent to which the elements work to reinforce each other. In this sense, as PPPs are largely products of institutions, these central and broad treatments of new institutionalism are thus relevant and powerful to orient the analysis and the discerning of on-going institutional complementation mechanisms as they occur in the peculiar Uganda PPP context.

\section{Materials and Methods}

We conducted an explorative case study on how different policy, operative, regulatory actors in the electricity distribution partnership in Uganda institutionally adapted the partnership to respond to emergent challenges at the implementation phase. We particularly focused on experiences of individual actors in electricity sector regulation, electricity sector policy formulation, and executives of the implementing entities and consultants that are directly currently and previously involved in the partnership implementation phase. We used document analysis and semi-structured interviews. For the first of these, research studies, legal documents, statements and press releases from different actors were analyzed qualitatively to gain a better understanding of the formal institutions, the relevant (corporate) actors, and the actor constellation, as presented in Appendix 1.

Second, we considered a data set of 15 semi-structured interviews with individual actors within regulation, policy, consultancy and implementation as portrayed in Appendix 2. The initial interviews involved representatives from the organizations involved in the implementation of the partnership, from which further interviewees were purposively identified through snowball sampling. Snowballing has also been successfully utilized in some of the most recent PPP studies where there is a limited access of relevant participants due to project confidentially and perceived sensitivity of the research topic (Opawole and Jagboro, 2017; Yang et al., 2018). In this case the number of relevant participants was limited given the relatively new phenomenon of PPP in Uganda and the current media and public scrutiny that the case study project was under at the time of data collection (February - July 2018). The empirical data was analyzed through a code system and aided by qualitative data analysis software NVIVO version 11. Content analysis (Bernard and Ryan 2010; Kuckartz 2014) deductively oriented by the elements of theoretical framework, as highlighted in the

International Journal of Management and Applied Research, 2021, Vol. 8, No. 2 
preceding section, was then performed. The operationalization of analysis followed the first order coding and second order coding protocol (Saldaña, 2015). In the first, all observations from documentary data and interview transcripts indicating or suggesting actions and/or decisions undertaken by actors were coded to predetermined conceptual categories inform of excerpts. In the second order, excerpts were iteratively recategorised based on relatedness in substantive meaning to generate three thematic categories of institutional complementation mechanisms presented and discussed.

\section{The Project and National Context}

This electricity distribution concession is the largest single electricity distribution PPP in Uganda. It distributes to $80 \%$ of the market and manages $100 \%$ of the urban distribution network. The concession contract was signed on the $17^{\text {th }}$ of May 2004. The Uganda Electricity Distribution Company Limited (UEDCL) and UMEME Limited are the principal public and private partners, respectively. The partnership is part outcome of the power sector reform of the late 1990s to early 2000s in which the vertically integrated government parastatal, Uganda Electricity Board (UEB), was unbundled to create different units. Three business units were created including Uganda Electricity Generation Company Limited (UEGCL), Uganda Electricity Transmission Company Limited (UETCL) and Uganda Electricity Distribution Company Limited (UEDCL) in charge of generation, transmission and distribution respectively. These units were incorporated as public companies in 2001.

In 2004, distribution network assets were leased to UMEME Limited on concession arrangement for a period of twenty (20) years from 2005 to 2025 under the model Operate-Maintain-Transfer. The terms and conditions of this concession are spelt out in the series of agreements that constitute the concession package. These include the lease and assignment agreement, the distribution support agreement. Following the agreement, distribution and supply of electricity licenses were issued to UMEME by the Electricity Regulatory Authority. Table 1 highlights important features of the PPP project.

Table 1: The Key Case study Project Features

\begin{tabular}{|c|c|}
\hline Feature & Details \\
\hline Scope & National (within authorized territory) \\
\hline PPP objective & Distribution and supply of electricity in the authorized territory \\
\hline $\begin{array}{l}\text { Type of agreement } \\
\text { between parties }\end{array}$ & A concession \\
\hline Contractual & Lease and assignment agreement (with UEDCL), \\
\hline instruments & Distribution support agreement (with Government), \\
\hline & Licenses for distribution and supply (with ERA), \\
\hline & Power Purchase Agreement (with UETCL) \\
\hline $\begin{array}{l}\text { Implementation } \\
\text { model }\end{array}$ & Operate-Maintain-Transfer \\
\hline Concession term & 20 years \\
\hline Partnership phase & Operation (implementation) \\
\hline Value of investment & Approx. \$500million (2018) \\
\hline
\end{tabular}

International Journal of Management and Applied Research, 2021, Vol. 8, No. 2 
PPP actors

Financial structure
UMEME Limited, UEDCL, ERA, UETCL, Ministry of Finance, Planning and Economic Development

Investors' contributions in exchange for shares of stock, Selling corporate bonds, User tariffs Tariffs set by the regulatory authority

Source: own work

Uganda has engaged with different forms of private sector participation in public services and infrastructure delivery for a long time, and some form public private partnership since the early 2000s. For the most part, the private sector participation took the traditional procurement and outsourcing forms with the relationship between the private and private sectors being purely a commercial transaction nature. From the early 2000s range of factors have drove an unprecedented adoption and application of collaborative models involving long-term partnerships between the private sector and the public sector in the service and infrastructure provision in Uganda. World Bank (2017) report indicates that there are 24 active PPPs in Uganda, across the energy, transport and telecommunications sector and the majority of these are in the electricity sub-sector.

The genesis of the modality in Uganda can be traced to three prominent drivers including, the international proliferation of market driven ideals, of the 1980s and early 1990s, urging for more efficiency in the public sector (Bennell, 1997; Onyoin and Bovis, 2021), the increasing need for the complementation of the resources required for the investment in the economic and social infrastructure in the country (World Bank, 2017), the rampant inefficiencies in the public sector translating into failure to provide the much needed public services provide further rationalisation. These factors were and remain the central rationales PPP adoption as policy instrument in Uganda. On the basis of these rationales, the involvement of the private sector through formal PPP modality occurred as part of the economic liberalization agenda, although agenda mainly involved outright privatization of formerly owed government business entities. By 30 June 2011, the Uganda government had conducted 39 liquidations and 95 sell off transactions of the over 130 government owned entities in 1986 (Uganda News Releases, 2015). Most of them were divested through sale of assets, share sale, joint ventures and pre-emptive rights. Others were disposed through other approaches such as initial public offerings, concessions, auctions, debt equity swap and repossessions (Bennell, 1997; Onyoin and Bovis, 2021).

Prior to the sale, the enabling law, the Public Enterprises Reform and Divestiture Act (PERD Act) of 1993, clustered the entities in into. The first class included enterprises the state is required to retain one hundred percent shareholding, the second cluster included those enterprises in which the state was supposed to retain majority shareholding, and the third class were to be divested following the prescribed legal guidelines. It is the second class of enterprises that set the foundation for ongoing and long-term private and public participation.

International Journal of Management and Applied Research, 2021, Vol. 8, No. 2 
The long-term control of the electricity distribution partnership is premised on the contractual agreements between the private and public actors. This includes the lease and assignment agreement and the distribution support agreement. As articulated in the extant literature, such agreements remain incomplete either out of necessity, choice or capacity, thus necessitate actors to continually complement for their incompleteness in an ongoing. Therefore, in the course of operation, these institutional gaps need to be filled in preparation for or as a response to challenges faced (Onyoin, 2021). In the context of extant research in partnership control and institutional theory, the following section discusses the important findings on the different mechanisms of institutional complementation adopted by the actors and subsequently discerns further implications for PPP management. In other words this section addresses how actors fill institutional gaps that become apparent in the course of implementation.

\section{Findings and Discussion}

Our analysis of the evidence fundamentally reveals the primacy of different actions and decisions executed by the different actors acting independent and/or collectively. As elaborated later in this section, these actions and decisions are by actors are aimed at clarifying, adapting or reinforcing the existing institutions to enable them respond to emergent challenges. These actions and decisions are thematically categorized into three including a) contractual renegotiations and amendments, b) development of new guidelines, and c) development of multiactor-inclusive coordinating structures. Each of these is elaborated, exemplified and discussed in the context of available research and of institutional theory in the following sections below.

\subsection{Re-negotiation and Amendment of Contractual Provisions}

Making changes to the existing contractual provisions is one important way in which actors adapt control institutions to respond to the challenges in the course of implementation. Broadly, the evidence indicates that adjustments to the clauses in agreements, licenses and law have to adapt the rules to the nature of challenges. The areas and the reasons for which renegotiation and amendment of the rules has been necessitated are noted and or suggested. The revisions to the existing institutional framework have been occasioned in the form of revision of targets, changes in the parameters of assessment for the partnership performance, tariff setting methodology, in investment verification, and reporting guidelines, as the excerpt from a senior corporate planning executive in the sector regulatory authority illuminates.

I recall there was a drought I think 2006 -7 which necessitated the revision of some of those (contractual) clauses. There was a minimum amount of power (hydroelectricity) which UETCL (Uganda Electricity Transmission Company Limited) was supposed to sell to UMEME but because of the drought (that occasioned reduced power generation) they (UETCL) could not sell that power. So I remember there was something around revision of those special contract provisions (Interviewee 9, 2018).

International Journal of Management and Applied Research, 2021, Vol. 8, No. 2 
The changes also addressed emergent requirements to protect consumer interest (Interviewee 10, 2018) settle dispute between actors (Interviewee 7, 2018), and in some instances amendments used as restitution of affected partners from unanticipated occurrences (Interviewee 9, 2018). These, as the excerpt from the senior private sector partner executive below illustrates,

For example, we (partners) had a dispute over our license and we were able to sit down and agree, (and) we modified it. It is not yet complete, it is going through another mediation until we reach that point where we believe that both parties address the core of dissonance without compromising the public's or the customers interests (Interviewee 7, 2018).

In light of extant research on PPPs across the services and infrastructure domains and the theory of institutions, a number of observations can be made from this mechanism. In particular, making adjustments to the prevailing institutions reinforces some known observations in extant research and theory that also include suggestions for caution. First, the mechanism reinforces and extends an established notion of incompleteness of contracts as control instruments (Cohen and Boast, 2016; Hart, 2003; Onyoin, 2021; Sadran, 2004; Stafford \& Stapleton, 2017).It specifically suggests that in the context of PPPs operational issues relating to the services delivery, changes in expectations in regard to quality and quantity of the service expectations of the different stakeholders are bound to change and thus require respective changes to the initial sets of provisions relating to those aspects. In this respect, the contractual provision is adapted to meet the specific requirements.

Secondly, the finding suggests that the initial provisions in the contract are limited in anticipation both in scope and complexity of interests of stakeholders. This links to previous observations on the multi-dimensional complexity of PPPs that is difficult to precisely anticipate at the pre-contractual phase when negotiations occur(Sadran, 2004). Moreover, amending existing institutions as depicted here, and for reasons noted, reinforces earlier suggestions that perhaps there is nothing wrong with the incomplete contracts as they can be used to create incentives for the private sector provided the public sector is equipped to negotiate and monitor large contracts, ongoing commercial collaboration and dispute resolution as well as including regular updates (Cohen \& Boast, 2016; Hodge, Boulot, Duffield, \& Greve, 2017).

The positive complementation notwithstanding, this finding also places in perspective the possibility that contract incompleteness may exacerbate partner opportunism with partners using or attempting to utilise contractual gaps to extend self-interest, often at the detriment of the other. Although in this regard, as some argue, 'these complex and lengthy documents must attempt to cover all potential aspects of the project over its long life' (Stafford \& Stapleton, 2017, p. 383), the fact that such can hardly be achieved in the context of PPPs leaves possibility of opportunity for improvement as much as risk of opportunism.

International Journal of Management and Applied Research, 2021, Vol. 8, No. 2 
From a theory context, the evident processes leading to the contractual amendments point to the social construction of institutions undertaken by the actors. In particular, undertaking renegotiation spells the intention of actors to adjust the existing rules in light of reality experienced rather attempting to apply the rule only as set out.

\subsection{Development of New Regulatory Guidelines and Standards}

In addition to changes to the contractual instruments and to the prevailing institutional frameworks, enactment of new guidelines and standards is important mechanisms to fill the gaps in existing rules. In this case, they the development of investment approval and verification guidelines(Interviewee 7, 2018; Interviewee 11, 2018; Interviewee 12, 2018), bulk meeting with the development of bulk metering guidelines(Interviewee 9, 2018), as the quote below illustrates.

In the past the investment verification was not streamlined but lately they have improved and have gone ahead to issue what they call investment guidelines so that it reduces on the risk from both sides. From UMEME side, undertaking an investment that would eventually be disallowed, and on the other hand the regulator is not seen as a risk. They have tried to bring down that risk by having a meeting of minds that they (UMEME) do not start something that has not gone through the due process of approval by the regulator(Interviewee 11, 2018).

The other complementary guidelines include are the tariff guidelines and the quality of service standards along with attendant penalties and incentives (Interviewee 9, 2018).

This mechanism suggests three important issues in relating to filling institutional gaps in the context of this case. First, the primacy of sector regulator and the regulatory instrument as an unconsidered PPP control authority particularly in regulated sector context. In this case, at the pre-contractual point of negotiating the contract the regulator was not involved yet in reality its avenue to exert control over the PPP becomes apparent during implementation and when dispute is outside the scope of the contract emerge. In this regard, while regulation based institutions can act as remedies in situations of institutional gaps, it suggests a possibility of institutional supremacy contestation in which the negotiated contract agreements and the oversight regulatory instruments can conflict. This becomes, in its self, an institutional gap that might require remedy for PPPs in operating in independently regulated sectors.

Relatedly, this finding suggests a possibility of deliberate and/or inadvertent transfer of authority from the partners to the regulator through oversight rules that go beyond complementing for the institutional gaps to undermining contractual authority of such institutions. This leaves the actors in a state in which they will be perpetually negotiating scope of control between the contractual based institutions and the regulatory institutions. This will be particularly pronounced in circumstance where the interests of partners, initially provided for and protected through the contractual provisions, are risked or are perceived to at risk by the new or modified set of regulatory rules.

International Journal of Management and Applied Research, 2021, Vol. 8, No. 2 
Thirdly, the findings suggest that regulation based institutions are used to adapt the partnership to out of scope issues, particularly, involving the interest of the public. The observations on issues addressed through regulation based institution precisely depict the power of the regulatory to mainstream this issues that were either deliberately or inadvertently not provided for in the stream set of institutions. In regard to institutional theory actions are consistent with the assumptions of the social construction of institutions, particularly as it pertains to drawing on the view of actors at the time and the determination of courses of action informed by the so called 'principles of appropriateness'(March and Olsen, 2008).

\subsection{Establishment of Inclusive Sector Wide Coordinating Structures}

Finally, as the context description illustrates, the value chain in the electricity service provision sets a context of inevitable and high interdependences among actors. In this regard, the decisions and actions of any of the actors will have an important bearing on the functioning of the others. In other words, any changes in the decision of any of the value chain partners will most likely impact the functioning of the others. This then requires ongoing alignment of decisions of various actors across the value chain. The evidence in this case however indicates that while these interdependences are significant, the existing institutional framework does not adequately provide sufficient controls against actor discretion in decision making in this complex interactions. To that end, the interviewee evidence indicates attempts by actors to align at a sector level by creating inclusive structures that serve to coordinate decisions, interests and actions of the interested parties. These structures are not provided for in the partnership existing institutional framework but have been found necessary to complement the existing institutions.

Some of the important structures that have so far been created to coordinate the actions at the sector level yet not explicitly provided for in the partnership agreement include, first, the grid committee, whose membership includes representatives from electricity generators, transmitter, distributors, and other interest groups, as the excerpt below elaborates.

I know there are also other things, like a grid code committee, where we have ERA representation. So all the major (sector) players are in the room and they are considering which are the major (electricity connection) lines coming on board, what is the demand projection, things like that. Where they can agree on a high level on what are the key interventions required and those are usually hosted by the minister so different players working together(Interviewee 9, 2018).

The general purpose of the code is to provide rules and procedures for the efficient management of the electricity supply industry in Uganda, taking into account a wide range of operational conditions that are likely to be encountered under normal and exceptional circumstances (The Uganda Grid code, p11, (Interviewee 9, 2018).

International Journal of Management and Applied Research, 2021, Vol. 8, No. 2 
Secondly, the sector working group that coordinates the sector wide interventions of different players and harmonises the different expectations and course of actions(Interviewee 1, 2018; Interviewee 7, 2018), thirdly, system planning and coordination committee that mainly considers investment plans and priorities and reconciles the agendas of the participating actors in the sector(Interviewee 6, 2018). The quote below illuminates the structures and central rationale.

[...] what we did was we moved towards integrated sector planning. So previously we (UMEME) would run our investment without transmission (UETCL) so what we said no let us sit on the same table. So that we there, there is the regulator, UEDCL, Transmission, there is REA (Rural Electrification Agency) here, there is Finance (ministry), there is energy (ministry) there...... So we have seen through that collaboration most of the things are being done and there is total transparency on who is doing what (Interviewee 1, 2018).

Based on the nature of the specific response actions, the inadequacy suggested can be interpreted in the context of available research in three different but nonexclusive ways. The first that reinforces earlier observation is that the set of institutions, in this case the concession agreements, are not comprehensive enough to address all the important issues. Therefore, there was a need to institutionally address the underestimated and unforeseen issues involving changes in expectations and realities of different stakeholders. The second suggestion is that the institutions are not sufficiently instructive and leave room of actor conflicting interpretations of the courses of actions.

In other words, although it might not be possible for contract to articulate step by step instructive courses of action on all the issues considered, it is a realization, in the context of this study, that such will require to be specified in the course of interaction between partners. Lastly, it appears from the finding that at the formative stages the instrumental actors and how they would affect the functioning of the partnership was not adequately articulated and it was an important oversight not to structure their role in the partnership.

In the context of theory, institutionalism aligns with the concept of social construction of institutions (DiMaggio, 1998; Hall and Taylor, 1996; March and Olsen, 2008). By social construction of institutions, the practices and/or actions of actors emerge from interactive processes, where actors share with each other interpretations to problems and ways of solving them. In this case, the actions undertaken indicate that actors jointly and interactively undertook the processes of establishing and operationalizing the actor-inclusive structures. Moreover, the enactment of these committees suggests that actors reached common understanding of problems and necessity of enacting new institutions as solutions to the problem. And as such acted in line with embedded practices of collectivity and mutual understanding of what is true, reasonable, natural, right and good for a specific situation (March and Olsen, 2008).

\section{Conclusion and Implications}

International Journal of Management and Applied Research, 2021, Vol. 8, No. 2 
This case study has utilized direct actors experiences to demonstrate Public Private Partnerships as incomplete contracts and illustrated the efficacy of three socially constructed mechanisms as remedies to the unavoidable and sometimes deliberate and necessary institutional gaps. Moreover, this study has suggested important areas and issues in the course of PPP implementation that contractual provisions are least able to anticipate precisely and institutionally provide for and as such less capable to provide direct and immediate redress. Understanding how actors redress in the course of PPP implementation has been an outstanding gap that this study fills.

Remedially, the case study has specifically showed that in PPP context that is characterized by emergent realities, institutionally unanticipated, the institutional gaps are complementarily filled through socially constructed institutions. The findings have primarily distinguished the institution complementation mechanisms into three: (1) renegotiation and amendment of contractual provisions: mostly crucial for adapting the existing provisions to the realities experienced; (2) development of new regulatory standards, guidelines and protocols: mostly crucial for mainstreaming aspects of broader public interest and concern in the institutional routine of PPP implementation, and (3) establishment of inclusive sector wide coordinating structures: mostly helpful in institutionally mainstreaming the input of all relevant actors in the PPP service value chain.

The direct observations and suggestions of these findings hold significant implications for PPP practice in Uganda's electricity sector, other sectors with similar structural setup in other countries, PPP practice in developing countries with similar political and socio-economic conditions to Uganda. Firstly, findings indicate that PPP actors ought to acknowledge that in the complex context of PPPs, institutional gaps will unavoidably and sometimes deliberately exist in PPP contracting process. These are occasioned often by the circumstances outside the immediate control and purview of the contracting actors during planning and later in operation. This suggests that in addition to the consideration of interests of the principal contracting parties, it is important to map the relevant service value chain actors and institutionally mainstream them at the contracting phase. Secondly, the significance of the specific the sector structure and its influence on the effectiveness of the contracting process. In this case, the practical learning is that the usual format of bundling of activities under PPP may not generate the same control level in the context of highly integrated and vertically integrated sector or service. This suggests that developing effective internal control for PPPs requires a peculiar consideration of the sector structure and designing integrated contracting process in which the role of other values actors are mainstreamed.

Furthermore, this study displays the double edged and integral role of sector wide regulator, which poses both an opportunity and threat to the internal management processes. The fact that the regulator can influence actions and decisions of the partners in the PPP through the regulatory powers, for instance by setting new or modifying guidelines and standards, has double edged potential. As an opportunity, such authority can be used to support institutions in an ongoing manner. As risk, regulatory powers maybe used opportunistically. Therefore, in the context of regulated sector, the use of PPPs creates two institutional regimes whose scope of authority need

International Journal of Management and Applied Research, 2021, Vol. 8, No. 2 
to be reconciled early at the contracting phase and subsequently on continual basis to adapt both regimes to emergent realities.

Although the study findings generate such important implications for PPP practice, the suggestions made maybe limited by the peculiar setting of this investigation. In particular, there are significant context considerations such as the electricity sector structure, country experience with the PPP modality and the PPP type that created unique experiences reported by the actors in the Uganda electricity sector. This shows that future studies can attempt to address the question by varying these contextual elements. Future investigations may also compare and contrast experiences in PPP projects in sectors regulated through licenses issued by independent authority and those controlled purely by PPP contract.

\section{References}

1. Bennell, P. (1997), "Privatization in sub-Saharan Africa: Progress and prospects during the 1990s", World development, Vol. 25, No. 11, pp. 1785-1803. https://doi.org/10.1016/S0305-750X(97)00068-5

2. Bovis, C. (2014), Public-private partnerships in the European Union. UK: Routledge.

3. Cantarelli, C. C., van Wee, B., Molin, E. J., and Flyvbjerg, B. (2012), "Different cost performance: different determinants? The case of cost overruns in Dutch transport infrastructure projects", Transport Policy, Vol. 22, pp. 88-95. https://doi.org/10.1016/j.tranpol.2012.04.002

4. Cohen, R. and Boast, T. (2016), "Governance of Public-Private Partnerships and Infrastructure Delivery: Case of the Milan, Italy, Metro Line M4", Transportation Research Record, Vol. 2597, No. 1, pp. 37-43. https://doi.org/10.3141/2597-05

5. De Schepper, S.; Dooms, M. and Haezendonck, E. (2014), "Stakeholder dynamics and responsibilities in Public-Private Partnerships: A mixed experience", International Journal of Project Management, Vol. 32, No. 7, pp. 1210-1222. https://doi.org/10.1016/j.ijproman.2014.01.006

6. De Schepper, S.; Haezendonck, E. and Dooms, M. (2015), "Understanding precontractual transaction costs for Public-Private Partnership infrastructure projects", International Journal of Project Management, Vol. 33, No. 4, pp. 932-946. https://doi.org/10.1016/j.ijproman.2014.10.015

7. Demirel, H. Ç.; Leendertse, W.; Volker, L., and Hertogh, M. (2017), "Flexibility in PPP contracts-Dealing with potential change in the pre-contract phase of a construction project", Construction Management and economics, Vol. 35, No. 4, pp. 196-206. https://doi.org/10.1080/01446193.2016.1241414

8. DiMaggio, P. (1998), "The new institutionalisms: avenues of collaboration", Journal of Institutional and Theoretical Economics (JITE)/Zeitschrift für die gesamte Staatswissenschaft, Vol. 154, No. 4, pp. 696-705.

International Journal of Management and Applied Research, 2021, Vol. 8, No. 2 
9. Flyvbjerg, B.; Skamris Holm, M. K., and Buhl, S. L. (2003), "How common and how large are cost overruns in transport infrastructure projects?", Transport Reviews, Vol. 23, No. 1, pp. 71-88. https://doi.org/10.1080/01441640309904

10. Hall, P. A. and Taylor, R. C. (1996), "Political science and the three new institutionalisms", Political studies, Vol. 44, No. 5, pp. 936-957. https://doi.org/10.1111/j.1467-9248.1996.tb00343.x

11. Hart, O. (2003), "Incomplete contracts and public ownership: Remarks, and an application to public-private partnerships", The Economic Journal, Vol. 113, No. 486, pp. C69-C76. https://doi.org/10.1111/1468-0297.00119

12. Hodge, G.; Boulot, E.; Duffield, C. and Greve, C. (2017), "After the Ribbon Cutting: Governing PPPs in the Medium to Long Term", Australian Journal of Public Administration, Vol. 76, No. 3, pp. 330-351. https://doi.org/10.1111/14678500.12239

13. Johnston, J. and Gudergan, P. S. (2007), "Governance of public-private partnerships: lessons learnt from an Australian case?", International Review of Administrative Sciences, Vol. 73, No. 4, pp. 569-582. https://doi.org/10.1177\%2F0020852307083459

14. Koppenjan, J. (2005), "The Formation of Public-Private Partnerships: Lessons from Nine Transport Infrastructure Projects in The Netherlands", Public Administration, Vol. 83, No. 1, pp. 135-157. https://doi.org/10.1111/j.00333298.2005.00441.x

15. March, J. G., and Olsen, J. P. (2008), "Elaborating the new institutionalism", in: Binder, S. A. Rhodes, R. A. W. and Rockman, B. A. (Ed.), The Oxford Handbook of Political Institutions. https://doi.org/10.1093/oxfordhb/9780199548460.003.0001

16. Meyer, J. W. and Rowan, B. (1977), "Institutionalized Organizations: Formal Structure as Myth and Ceremony", American Journal of Sociology, Vol. 83, No. 2, pp. 340-363. https://doi.org/10.1086/226550

17. Newberry, S. and Pallot, J. (2003), "Fiscal (ir)responsibility: privileging PPPs in New Zealand", Accounting, Auditing \& Accountability Journal, Vol. 16 No. 3, pp. 467-492. https://doi.org/10.1108/09513570310482318

18. Onyoin, M. (2021), "Understanding Post Contractual Turbulence in Public Private Partnerships: Themes and Issues", International Journal of Management and Applied Research, Vol. 8, No. 1, pp. 51-71. https://doi.org/10.18646/2056.81.21004

19. Onyoin, M. and Bovis, C. (2021), "Policy and institutional enablers of publicprivate partnerships in the electricity sector in Uganda: a multi-level and path dependence perspective", International Journal of Public Sector Management, Vol. 34 No. 1, pp. 51-70. https://doi.org/10.1108/IJPSM-01-2020-0026

20. Opawole, A. and Jagboro, G. O. (2017), "Factors affecting the performance of private party in concession-based PPP projects in Nigeria", Journal of Engineering, Design and Technology, Vol. 15, No. 1, pp. 44-57. https://doi.org/10.1108/JEDT-09-2015-0058

International Journal of Management and Applied Research, 2021, Vol. 8, No. 2 
21. Peters, B. G. (2019), Institutional theory in political science: The new institutionalism, $4^{\text {th }}$ ed., UK: Edward Elgar Publishing.

22. Powell, W. W., and DiMaggio, P. J. (2012), The new institutionalism in organizational analysis, USA: University of Chicago press.

23. Sadran, P. (2004), "Public Private Partnership in France: A Polymorphous and Unacknowledged Category of Public Policy", International Review of Administrative Sciences, Vol. 70, No. 2, pp. 233-251. https://doi.org/10.1177\%2F0020852304044253

24. Saldaña, J. (2015), The coding manual for qualitative researchers, $3^{\text {rd }}$ ed., UK: Sage.

25. Scott, W. R. (2010), "Reflections: The past and future of research on institutions and institutional change", Journal of change management, Vol. 10, No. 1, pp. 5-21. https://doi.org/10.1080/14697010903549408

26. Stafford, A. and Stapleton, P. (2017), "Examining the Use of Corporate Governance Mechanisms in Public-Private Partnerships: Why Do They Not Deliver Public Accountability?", Australian Journal of Public Administration, Vol. 76, No. 3, pp. 378-391. https://doi.org/10.1111/1467-8500.12237

27. Trebilcock, M. and Rosenstock, M. (2015), "Infrastructure Public-Private Partnerships in the Developing World: Lessons from Recent Experience", The Journal of Development Studies, Vol. 51, No. 4, pp. 335-354. https://doi.org/10.1080/00220388.2014.959935

28. World Bank. (2017), Infrastructure finance deficit: Can public-private partnerships fill the gap? [Online] Available from: https://www.worldbank.org/en/country/uganda/brief/infrastructure-finance-deficitcan-public-private-partnerships-fill-the-gap [Accessed on 1 May 2021].

29. Uganda News Releases (2015), Privatisation: Explaining Museveni's U-turn. [Online] Available from: https://www.ugandanewsreleases.com/\%EF\%BB\%BFprivatisation-explainingmusevenis-u-turn/ [Accessed on 2 May 2021].

30. Van den Hurk, M. (2016), "Learning to contract in public-private partnerships for road infrastructure: recent experiences in Belgium", Policy Sciences, Vol. 49, No. 3, pp. 309-333. https://doi.org/10.1007/s11077-015-9240-y

31. Yang, R.J.; Jayasuriya, S.; Gunarathna, C.; Arashpour, M.; Xue, X. and Zhang, G. (2018), "The evolution of stakeholder management practices in Australian mega construction projects", Engineering, Construction and Architectural Management, Vol. 25 No. 6, pp. 690-706. https://doi.org/10.1108/ECAM-07-2016-0168

32. Zucker, L. G. (1987), "Institutional Theories of Organization”, Annual Review of Sociology, Vol. 13, No. 1, pp. 443-464. https://doi.org/10.1146/annurev.so.13.080187.002303

International Journal of Management and Applied Research, 2021, Vol. 8, No. 2 


\section{Appendix 1: Empirical documents used in the analysis}

1. UMEME Concession Agreement

2. Power Supply Agreement between UETCL \& UMEME

3. GOU UMEME Support Agreement

4. 2nd Amendment to GOU UMEME Support Agreement

5. 3rd Amendment to GOU UMEME Support Agreement

6. 4th Amendment to GOU UMEME Support Agreement

7. Modification of License No.046 for the supply of electricity

8. Licence for Supply of Electricity Amendment Number Three $1^{\text {st }}$ March 2012

9. Licence Supply of Electricity Amendment One Dec 2006

10. Licence Supply of Electricity Amendment Two Feb 2012

11. UMEME Licence Distr Elec No.047 2005

12. UMEME Sup Electricity No. 0482005

13. Letter relating to Amendment No 4

14. Public Enterprises Reform and Divesture Act 1993

15. Electricity Act 1999

16. Public Private Partnership Act 2015

17. ERA Presentation to the Media 2018

18. The Electricity (Application for Permit, License and Tariff Review) Regulations, 2007

19. Power Crisis brief-2

20. Power sector restructuring and Privatisation

21. Report on Electricity Tariff Reduction 2009 (2)-1

22. Briefing for Interim Tariff committee - ED PU

23. The Electricity (Application for Permit, License and Tariff Review) Regulations, 2007

24. The Electricity (Quality of Service Code) Regulations, 2003

25. The Electricity (Tariff Code) Regulations, 2003

26. Guidelines for Implementation of Bulk Metering by Electricity Distribution Licensees

27. Quality of Service Standards in the Electricity Supply Industry

28. Energy Rebate Guideline

29. Understanding your rights as an electricity consumer

30. Check List of Requirements For Qualifying Permit and License Applications

31. Electricity investment approval and verification guidelines

32. Electricity Consumer's Committee Manual

33. Guidance on permit and license applications

34. Electricity Consumer Protection Guidelines

35. Standardised Complaints Handling Guidelines for the Electricity Supply Industry

International Journal of Management and Applied Research, 2021, Vol. 8, No. 2 
Social Construction of Institutional Complementation in Cross Sector Collaborations: An Empirical Exploration of a Public Private Partnership Case

\section{Appendix 2: Interviewees}

\begin{tabular}{|c|c|}
\hline Interview code & Title \\
\hline Interviewee 1 & Managing Director, UMEME \\
\hline e 2 & $\begin{array}{l}\text { Private Legal consultant/Ex Director Legal Privatization Unit, } \\
\text { Ministry of Finance Planning and Economic Development }\end{array}$ \\
\hline Inter & Ex minister of Energy and Mineral Resources \\
\hline Inter & $\begin{array}{l}\text { Private Energy consultant/Ex. Managing Director, Electricity } \\
\text { Regulatory Authority }\end{array}$ \\
\hline Inter & $\begin{array}{l}\text { Presidential Advisor on Oil and Gas/Ex Permanent secretary - } \\
\text { Ministry of Energy and Mineral resources }\end{array}$ \\
\hline Inter & $\begin{array}{l}\text { Manager, Economic Regulation and Research, Electricity } \\
\text { Regulatory Authority }\end{array}$ \\
\hline Inte & tory financial controller, UMEME \\
\hline Inte & $\begin{array}{l}\text { Private legal practice/ Ex Legal Secretary, Electricity Regulatory } \\
\text { Authority }\end{array}$ \\
\hline Inte & r, Corporate Planning, Electricity Regulatory Authority \\
\hline 10 & Econ \\
\hline e 11 & $\begin{array}{l}\text { Private Engineering consultant/ Ex Director, Technical Regulation, } \\
\text { Electricity Regulatory Authority }\end{array}$ \\
\hline wee 12 & $\begin{array}{l}\text { Chief Finance Officer, Uganda Electricity Distribution Company } \\
\text { Limited }\end{array}$ \\
\hline ewee 13 & $\begin{array}{l}\text { Engineering Consultant/Ex Projects Manager/Quality Assurance } \\
\text { Manager, UMEME (SPV) }\end{array}$ \\
\hline In & Manager, Legal and compliance, Electricity Regulatory Authority \\
\hline Interviewee 15 & Manager, Pricing, Electricity Regulatory Authority \\
\hline
\end{tabular}

International Journal of Management and Applied Research, 2021, Vol. 8, No. 2 